\title{
Outdoor Performance Stability and Controlled Light-Soak Testing of Amorphous Silicon Multijunction Modules at NREL
}

L. Mrig, J. Burdick, W. Luft,

B. Kroposki

Presented at the

First World Conference on Photovoltaic Energy Conversion

December 5-9, 1994

Waikoloa, Hawaii

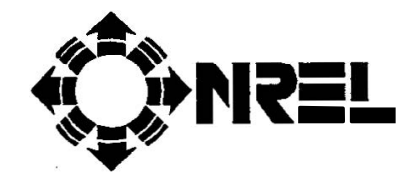

National Renewable Energy Laboratory 1617 Cole Boulevard Golden, Colorado 80401-3393

A national laboratory of the U.S. Department of Energy Managed by Midwest Research Institute for the U.S. Department of Energy under contract No. DE-AC36-83CH10093

Prepared under Task No. PV560101

October 1995 


\begin{abstract}
NOTICE
This report was prepared as an account of work sponsored by an agency of the United States government. Neither the United States government nor any agency thereof, nor any of their employees, makes any warranty, express or implied, or assumes any legal liability or responsibility for the accuracy, completeness, or usefulness of any information, apparatus, product, or process disclosed, or represents that its use would not infringe privately owned rights. Reference herein to any specific commercial product, process, or service by trade name, trademark, manufacturer, or otherwise does not necessarily constitute or imply its endorsement, recommendation, or favoring by the United States govemment or any agency thereof. The views and opinions of authors expressed herein do not necessarily state or reflect those of the United States government or any agency thereof.
\end{abstract}

Available to DOE and DOE contractors from:

Office of Scientific and Technical Information (OSTI)

P.O. Box 62

Oak Ridge, TN 37831

Prices available by calling (615) $576-8401$

Available to the public from:

National Technical Information Service (NTIS)

U.S. Department of Commerce

5285 Port Royal Road

Springfield, VA 22161

(703) $487-4650$ 


\title{
OUTDOOR PERFORMANCE STABILITY AND CONTROLLED LIGHT-SOAK TESTING OF AMORPHOUS SILICON MULTIJUNCTION MODULES AT NREL
}

\author{
Laxmi Mrig, Joseph Burdick, Werner Luft, and Benjamin Kroposki \\ National Renewable Energy Laboratory \\ Golden, Colorado 80401 U.S.A.
}

\begin{abstract}
The National Renewable Energy Laboratory (NREL) has been testing amorphous silicon (a-Si) Photovoltaic (PV) modules for more than a decade. NREL has been conducting controlled light-soak testing of multijunction a-Si modules to characterize their performance for stability evaluation as well as to benchmark the technology status. Some of the test modules, after controlled light-soak testing, have been installed outdoors. We have observed that under outdoor exposure, the modules further degrade in performance, possibly due to lower outdoor temperatures and varying spectra. The paper presents data on the light-induced degradation for the third controlled light-soak test on multijunction a-Si modules as well as outdoor performance data on single- and multijunction modules under prevailing conditions.
\end{abstract}

\section{INTRODUCTION}

The National Renewable Energy Laboratory (NREL) has been testing amorphous silicon (a-Si) photovoltaic (PV) modules since 1984, when the modules first became commercially available. Over the last few years, the technology focus, to a large extent, has been shifting from single-junction cell structure to multijunction configuration for reasons of higher efficiencies and improved stability. NREL has been conducting both outdoor and indoor controlled light-soak testing of multijunction a-Si modules to characterize their performance for stability evaluation and to benchmark the status of the technology. The controlled testing has been conducted in an environmental chamber with a fixed module temperature of $50^{\circ} \mathrm{C}$ and an irradiance of 1 sun, for periods ranging from $600 \mathrm{~h}$ to $2000 \mathrm{~h}$ under fixed maximum-power resistive loads. Two series of controlled light soak tests have been conducted on vintage 1990 and 1991 multijunction a-Si modules.[1],[2] After controlled light-soak testing, some of the test modules were installed outdoors at NREL's PV Outdoor Test Site to study their outdoor performance. We have observed that under outdoor exposure, the modules degrade further in performance, possibly due to lower outdoor temperatures and varying spectra.[3] A third series of controlled light-soak testing at NREL was initiated in 1994 and encompasses test specimens from major multijunction a-Si module manufacturers. In parallel with this controlled indoor lightsoak testing, some of the modules were deployed outdoors. The controlled light-soak test was performed, and $250 \mathrm{~h}$ data, in addition to one year of outdoor performance data, have been collected.

This paper presents the above-described long-term data on the outdoor performance of commercially procured single- and multijunction modules under prevailing conditions, as well as data on the performance of multijunction a-Si modules under outdoor exposure after the modules had been light-soaked under controlled conditions for a period of 2000 h.

\section{COMMERCIALLY PROCURED SINGLE- AND DUAL- JUNCTION a-Si MODULES}

\section{Single-Junction a-Si Modules:}

Figure 1 illustrates the performance of two single-junction, large-area, power modules by a U.S. manufacturer. It shows the normalized (to $1000 \mathrm{~W} / \mathrm{m}^{2}$ ) outdoor performance of the modules after an outdoor exposure of approximately 2 years. The measurements were taken under prevailing outdoor conditions. The modules experienced approximately 25\% $30 \%$ degradation in normalized power during the first 5 months of exposure. The data show that the modules have "stabilized" around 48-W normalized power. No temperature corrections have been applied to the data shown in the figure. Approximately $10 \%$ seasonal performance variation has been observed. Whether this seasonal variation is due to temperature or spectral effects is still being investigated.

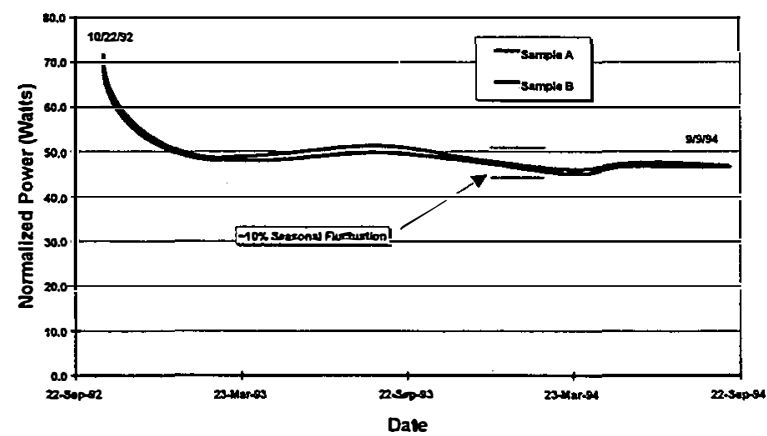

Figure 1. Single-junction a-Si performance

\section{Dual-Junction a-Si Modules:}

Figure 2 illustrates the performance of three commercially procured dual-junction a-Si modules under long-term outdoor exposure, since September 1991, at the NREL PV Outdoor Test Site. Current-Voltage (I-V) curve data were taken once every day around noon, when the irradiance was above 750 $\mathrm{W} / \mathrm{m}^{2}$. The power output is normalized to $1000 \mathrm{~W} / \mathrm{m}^{2}$; however, no temperature corrections are applied. The 
modules experienced an initial light-induced degradation of approximately $20 \%-25 \%$ in normalized power during the first few months of exposure. Since then, the modules appear to have stabilized in output, with seasonal performance variations of approximately $10 \%$.

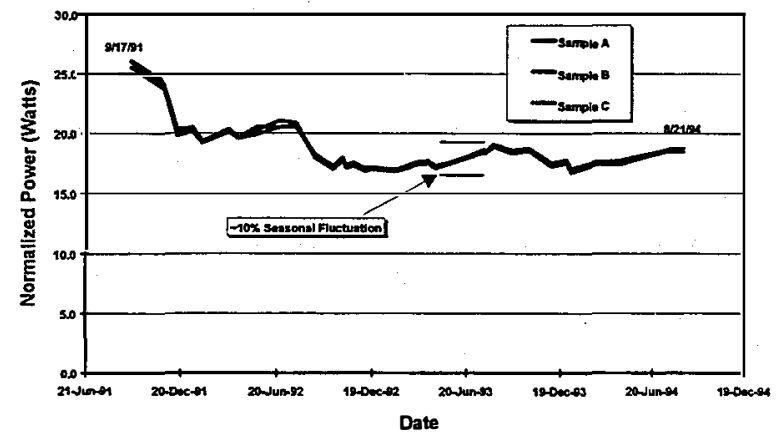

Figure 2. Dual-junction a-Si performance

\section{LIGHT-SOAK TESTING OF PROTOTYPE a-Si MODULES:}

The results of controlled light-soak tests \#1 and \#2 have previously been reported. ${ }^{1,2} \mathrm{~A}$ few of the test modules from these experiments were then deployed outdoors for exposure testing at the NREL Outdoor Test Site. These modules are monitored periodically for stability performance characterization. The following paragraphs describe their outdoor exposure performance.

\section{Outdoor Exposure of a-Si Modules after Light-soak Test \#1:}

Figure 3 illustrates the performance of one triple-junction and two dual-junction a-Si modules selected from the batch of modules in controlled light-soak test \#1, in which the modules were light-soaked for a period of $2000 \mathrm{~h}$. In NREL's lightsoaking equipment, an environmental chamber with a filtered argon-arc light source simulating the solar AM1.5 spectrum (see Fig. 4) is utilized.[1],[2] The temperature uniformity of the test modules has been measured to be $\pm 4^{\circ} \mathrm{C}$, and the irradiance uniformity is within $\pm 5 \%$.

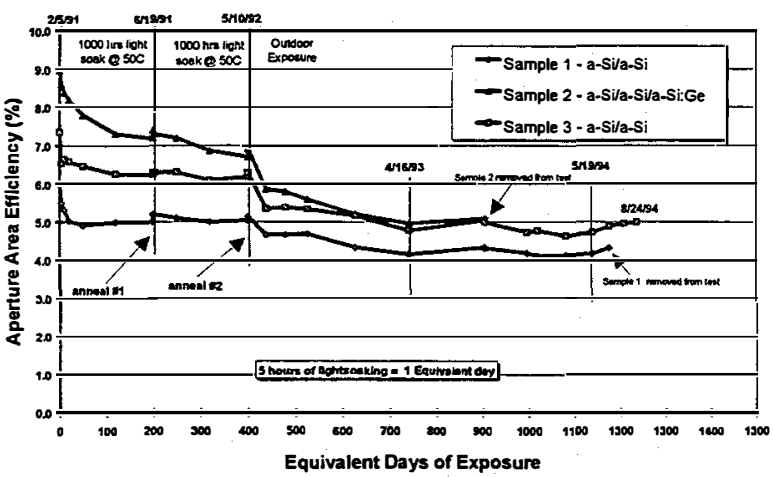

Figure 3. Performance of Light Soak \#1 a-Si modules

These three modules were then deployed outdoors under maximum-power load resistors. The graph indicates a decrease in performance of approximately $10 \%-15 \%$ of initial efficiency during an outdoor exposure period of approximately $2 \mathrm{yr}$ after the controlled light-soak exposure of $2000 \mathrm{~h}$. The data highlight the differences in stabilized performance between the indoor and outdoor light-soak testing of multijunction a-Si modules. It indicates a potential need to revise the present indoor light-soak criteria of $1000 \mathrm{~h}$ of constant 1 sun illumination at the module operating temperature of $50^{\circ} \mathrm{C}$ for determining a-Si module stability.

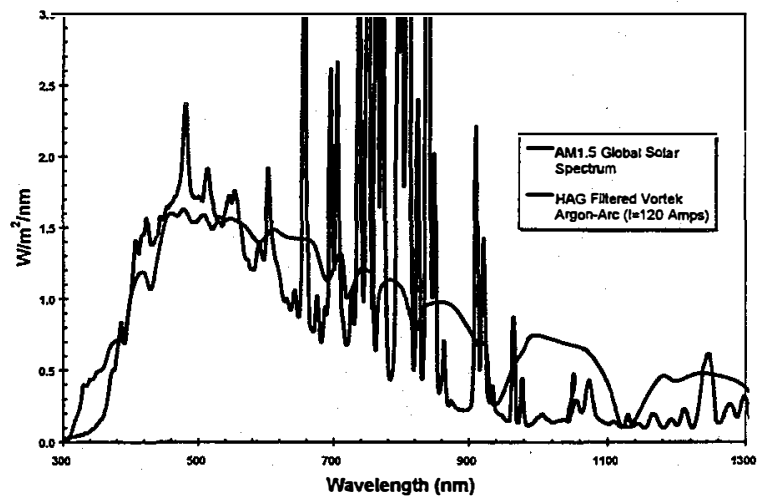

Figure 4. Comparison of Vortek argon-arc light source to ASTM standard solar Spectrum at AM 1.5 global

\section{Outdoor Exposure of a-Si Modules after Light-soak Test \#2:}

Figure 5 illustrates a similar difference in the indoor vs. outdoor stability performance for a dual-junction a-Si module selected from the batch of modules that completed the controlled light-soak test \#2. This module, after completing $2000 \mathrm{~h}$ of controlled light-soak testing, was deployed outdoors at the NREL test site to determine the outdoor performance. Although the module had stabilized in performance under controlled light-soak test indoors, it experienced approximately $10 \%$ additional degradation outdoors. Though the module, whose performance is illustrated in Fig. 5, is of newer vintage than the modules used in light-soak test \#1, the indoor vs. outdoor degradation differences are similar to the ones observed on the modules from light-soak test \#1.

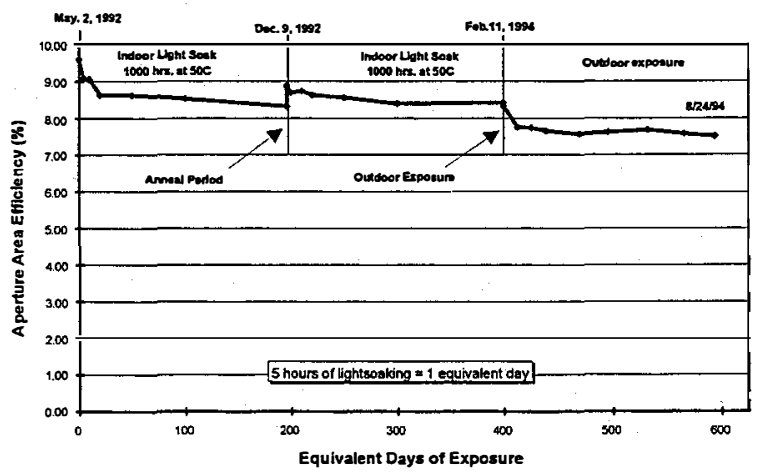

Figure 5. Performance of a Light Soak \#2 a-Si module 


\section{Light-Soak Test \#3 Results:}

The controlled light-soak test \#3 has completed $250 \mathrm{~h}$ of indoor light soaking. Several of the module types undergoing light-soak test \#3 have also been deployed outdoors and have completed 1 year of outdoor testing. The multijunction a-Si modules that are part of this test are from several U.S. and foreign a-Si manufacturers. The comparison of indoor vs. outdoor stability performance of five selected modules from one manufacturer is presented in Fig. 6 . These data also indicate higher outdoor light-induced degradation as compared to the controlled indoor light-soak test results similar to that observed from modules of light-soak tests \#1 and \#2.

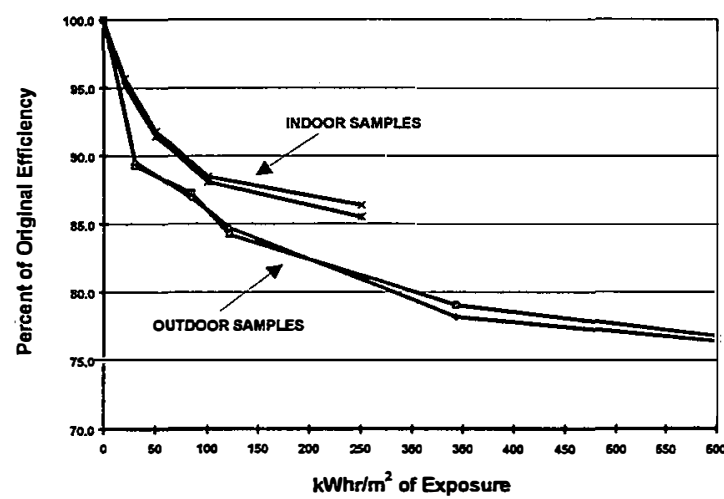

Figure 6. Indoor and outdoor performance comparison of triple-junction a-Si modules from Light Soak \#3

\section{CONCLUSIONS}

The a-Si modules that were commercially procured a few years ago and have been under long-term outdoor testing at NREL have degraded approximately $25 \%-30 \%$ prior to "stabilization" outdoors. Most of the degradation observed is due to the initial light-induced degradation that occurs during the first few hundred $\mathrm{kWh} / \mathrm{m}^{2}$ of exposure. The modules show an approximately $10 \%$ seasonal power variation in Golden, Colorado. This may be due to temperature variations, spectral influences, or a combination of both.

Another issue that needs further investigation and resolution is that additional degradation is observed in the stabilized performance of a-Si modules when they are deployed outdoors (in Golden, Colorado) after having undergone controlled light-soak testing indoors at $50^{\circ} \mathrm{C}$ for $1000 \mathrm{~h}$ at 1 sun constant illumination. This could be due to light exposure at lower temperatures experienced outdoors or due to the cyclic nature of the outdoor exposure (in terms of both illumination and temperature). Several options of controlled light-soak testing are planned to reduce the differences in degradation between indoor and outdoor stability characterization of a-Si PV modules.

\section{REFERENCES}

1. W. Luft, B. von Roedern, B. Stafford, D. Waddington, and L. Mrig, "Controlled Light-Soaking Experiment for Amorphous Silicon Modules," 22nd IEEE Photovoltaic Specialists Conference, 1991, p. 1393-1398.

2. W. Luft, B. von Roedern, B. Stafford, and L. Mrig, "Second Controlled Light-Soaking Experiment for Amorphous Silicon Modules," 23rd IEEE Photovoltaic Specialists Conference, p. 860-866.

3. W. Luft and B. von Roedern, "Considerations for LightSoaking of Amorphous Silicon Photovoltaic Modules," 1st World Conference on Photovoltaic Energy Conversion, (in press).

\section{ACKNOWLEDGEMENTS}

The authors gratefully acknowledge the contributions of $S$. Rummel, Y. Caiyem, L. Ottoson, and J. Pruett in conducting the tests and performing the measurements.

This work was supported by the U.S. Department of Energy under contract No. DE-AC36-83CH10093. 